\title{
Nonimmunoglobulin Fraction of Human Milk Inhibits the Adherence of Certain Enterotoxigenic Escherichia coli Strains to Guinea Pig Intestinal Tract
}

\author{
SHAI ASHKENAZI AND DAVID MIRELMAN \\ Department of Pediatrics A, Beilinson Medical Center, Petah Tiqva, Sackler School of Medicine, Tel Aviv \\ University, and Department of Biophysics, Unit for Molecular Biology of Parasitic Diseases, Weizmann Institute \\ of Science, Rehovoth, Israel
}

\begin{abstract}
The protecting effect of human milk against intestinal infections has been well documented, but its mechanism not completely understood. We have examined the effect of the nonimmunoglobulin fraction (NIgF) of human milk and colostrum on bacterial adherence to the intestinal tract. The NIgF was prepared by passing the milk through an immunosorbent column containing rabbit antihuman $\gamma$-globulin (IgG and IgA). The effluent fraction did not contain $\gamma$-globulins as shown by immunodiffusion on agarose and by using rabbit antihuman Ig, that was then detected with fluorescently-labeled goat antirabbit Ig. The effect of the NIgF of human milk on the adherence of enterotoxigenic Escherichia coli strains to guinea pig intestinal tract was quantitatively determined using radiolabeled bacteria which were incubated with suspensions of viable intestinal cells. Thirteen to 17 bacteria adhered per intestinal cell. NIgF of human milk and colostrum (300 $\mu \mathrm{l}, 6.7$ mg) caused about $50 \%$ inhibition of the adherence of enterotoxigenic $E$. coli strains whose attachment was mediated by colonization factor antigen I and II. No inhibition was noted on the adherence of enterotoxigenic $E$. coli strains containing type I pili. The inhibitory activity resisted boiling and proteolytic digestion with trypsin, but was completely abolished by periodate treatment, indicating that carbohydrate residues were probably involved. Examination of the effect of NIgF of human milk on bacterial adherence to intact intestinal surfaces revealed comparable results. Observations with scanning electron microscopy confirmed, morphologically, the attachment of the bacteria and the inhibitory effect of human milk. It is concluded that receptor-like glycocompounds in human milk and colostrum inhibit the adherence of certain enterotoxigenic $E$. coli strains to the intestinal mucosa. This may play a role in protecting infants against intestinal infections. (Pediatr Res 22: 130-134, 1987)
\end{abstract}

\section{Abbreviations}

ETEC, enterotoxigenic Escherichia coli

GI, gastrointestinal

SIgA, secretory IgA

CFA, colonization factor antigen

PBS, phosphate-buffered saline

NIgF, nonimmunoglobulin fraction

Received May 12, 1986; accepted February 19, 1987.

Address for correspondence and reprint requests D. Mirelman, Ph.D., Department of Biophysics, Weizmann Institute of Science, Rehovoth 76100, Israel.
Several studies have shown that breast-feeding protects against GI infections (1-3), and a committee who reviewed the literature concluded that association exists between breast-feeding and decreased rate of GI illness (4). The protective effect of human milk is usually attributed to its high content of $\mathrm{Ig}$, especially SIgA. However, Ig may be destroyed before reaching the small intestine, and as their titer is dependent on exposure of the mother to infectious microorganisms (5), it was suggested that their importance in developed countries is limited (6). Human milk contains other defense factors, such as lactoferrin (7), lysozyme, T and B lymphocytes, and phagocytes (5), but their biological significance has not as yet been clarified.

Bacterial adherence to epithelial surfaces has been increasingly studied in recent years and has been recognized as an important prerequisite for infection (8-10). Attachment to the intestinal mucosa is an obligatory pathogenic event in GI infections caused by enterotoxigenic bacteria, as it enables resistance to expulsion by peristaltic clearing mechanism, with subsequent enterotoxin production. Adherence is usually mediated by binding of bacterial surface proteins, called adhesins or lectins, to mammalian cell receptors $(9,10)$. Several surface antigens have been isolated from bacterial pathogens of animals (K88 and K99 antigens) and man (type I pili and CFA) (11). The host surface receptors are usually sugar residues, probably glycoproteins or glycolipids on cell membranes (9). This explains the competitive inhibitory effect of several carbohydrates on the adherence of specific bacteria $(9,12-14)$. Since human milk is rich in free oligosaccharides, glycoproteins, and glycolipids (15), and since its protection against gastroenteritis is not completely understood, it is possible that these compounds might be structural analogues to the intestinal receptors for bacterial pathogens and inhibit adherence. Indeed, Holmgren et al. (6) have shown that human milk inhibited Escherichia coli and Vibrio cholerae hemagglutination (6), which is dependent on bacterial attachment to erythrocytes.

We have recently described a system for studying bacterial adherence to guinea pig intestinal tract $(13,14,16)$. Herein we have directly examined the effect of NIgF of human milk on the adherence of ETEC strains to the gut.

\section{MATERIALS AND METHODS}

The effect of NIgF of human milk on bacterial adherence to guinea pig intestinal tract was quantitatively determined with the use of radiolabeled bacteria.

Bacteria. ETEC strains isolated from humans with severe watery diarrhea were used. E. coli $\mathrm{H} 10407$ and E1392-75 were obtained from J. Holmgren, University of Goteborg, Sweden, 
possessed CFA/I and CFA/II, respectively, and were grown as described (6). E. coli 0128:H4 was obtained from Dr. N. Gerber, Bar Ilan University, Israel, and was grown in 1\% peptone (Difco Laboratories, Detroit, $\mathrm{MI}), 0.5 \%$ yeast extract and $0.5 \% \mathrm{NaCl}$. It contained type I pili (14) and agglutinated mannan-containing yeast cells (12).

Radiolabeled bacteria were prepared by metabolically labeling them with $\mathrm{D}-\left({ }^{14} \mathrm{C}\right)$ glucose $(239 \mathrm{mCi} / \mathrm{mmol}, 0.1 \mathrm{Ci} / \mathrm{ml}$; The Radiochemical Center, Amersham, England) as described (13). The radioactivity of the labeled bacteria was counted in a Tricarb liquid scintillation spectrometer (model 3255, Packard Instrument Co., Downers Grove, IL) and the specific radioactivity obtained was approximately $10^{6}$ counts $/ \mathrm{min} / 10^{9}$ bacteria. Precipitation in 5\% trichloroacetic acid showed that more than $90 \%$ of the radiolabeled precursor was incorporated into macromolecular components of the bacteria.

Human milk and colostrum specimens. Pooled human milk (4-14 days after delivery) and colostrum (2-3 days after delivery) were obtained from Israeli women at the Beilinson Medical Center. The fresh milk was centrifugated $(10,000 \times g, 15 \mathrm{~min})$ and the clear middle layer was collected and separated from the upper and lower layers, which contained fat and cells, respectively, and frozen at $-30^{\circ} \mathrm{C}$. NIgF was obtained by passing the milk through an immunosorbent column which bound the immunoglobulins. The column consisted of a top layer of $2 \mathrm{ml}$ Sepharose 4B (Pharmacia Fine Chemicals, Uppsala, Sweden) covalently coupled with antihuman IgA ( $\alpha$ chain; Bioyeda, $\mathrm{Re}$ hovoth, Israel) and a bottom layer of $2 \mathrm{ml}$ Sepharose coupled with antihuman $\gamma$-globulin (heavy and light chains; Bioyeda). Each $\mathrm{ml}$ agarose contained $1.2 \mathrm{mg}$ Ig. The detailed procedures for preparation of the columns were as described $(6,17)$. After passage through the column, the nonbound fraction was recirculated through the column three times and then dialyzed against saline. This fraction was shown to be depleted of the various classes of immunoglobulins by immunodiffusion on agarose (Ouchterlony). In addition, the NIgF was devoid of any antibacterial Ig fraction as shown by the following experiment. Bacterial suspensions were incubated with $\mathrm{NIgF}$, washed $(\times 3)$, incubated $\left(30 \mathrm{~min}, 20^{\circ} \mathrm{C}\right.$ ) with rabbit antihuman $\gamma$-globulin (IgA and IgG), washed $(\times 3)$, and finally incubated $\left(30 \mathrm{~min}, 20^{\circ} \mathrm{C}\right)$ with fluorescent goat antirabbit $\gamma$-globulin (18). Only the original human milk fractions showed binding of fluorescent antibodies to the bacteria, confirming that antibodies against the bacteria examined were found only in the original human milk sample (in 1:10 dilution) and not in the NIgF. In order to quantitate this reaction and find out its sensitivity, experiments were done with increasing dilutions of the original human milk. It was found that this milk gave a positive reaction even at $1: 100$ dilution, indicating that this assay can detect as little as $1 \%$ of human milk immunoglobulins. The final NIgF fraction was lyophilized to obtain the dry weight, and its protein and sugar content were determined as described $(19,20)$.

Assay for bacterial adherence to viable intestinal cells. A suspension of intestinal cells was obtained by treating sections of the jejunum with solutions containing EDTA, citrate buffer, and dithiothreitol as described $(13,14)$. The viability of the intestinal cells was monitored by trypan blue exclusion. Radiolabled bacteria $\left(100 \mu \mathrm{l}, 2 \times 10^{9}\right.$ bacteria/ml $)$ were preincubated $(15 \mathrm{~min}$, $37^{\circ} \mathrm{C}$ ) with human milk [50-600 $\mu 1,(1.1-13.2 \mathrm{mg})$ according to the experiment] or the same volume of PBS in a rotating rack at $16 \mathrm{rpm}$. The bacteria were then incubated $\left(45 \mathrm{~min}, 37^{\circ} \mathrm{C}\right)$ with the intestinal cells $\left(200 \mu \mathrm{l}, 5 \times 10^{6}\right.$ cells $/ \mathrm{ml}, 200$ bacteria/cell $)$ with rotation. It was shown that no significant proliferation of the bacteria occurred during these incubation periods. The reaction was terminated by adding $2.5 \mathrm{ml}$ saline and centrifugation $(500 \times g, 5 \mathrm{~min})$ to sediment the epithelial cells, while the supernatant, which contained mainly nonadherent bacteria, was discarded. The separation of the epithelial cells from the remaining nonadherent bacteria was performed by discontinuous density-gradient centrifugation with Percoll (Pharmacia Fine Chem- icals, Uppsala, Sweden) $(13,14)$. The layer of epithelial cells with the adhered bacteria was collected and counted for radioactivity and the number of bacteria which adhered to the intestinal cells was quantitatively determined.

Assay for bacterial adherence to intact intestinal surface. Sections of guinea pig small intestine were obtained, washed with saline, and then opened by a longitudinal incision and placed on a flat plastic surface with the mucosa facing upward. A cover containing three oval holes with a surface area of $0.38 \mathrm{~cm}^{2}$ was screwed on the mucosal surface (13). Radiolabeled bacteria (100 $\mu \mathrm{l}, 2 \times 10^{9}$ bacteria $/ \mathrm{ml}$ ) were preincubated with human milk or PBS (control) as described above, and then were placed on the exposed portion of the mucosa (13). The preparation was incubated $\left(45 \mathrm{~min}, 37^{\circ} \mathrm{C}\right)$ in a humid chamber and the reaction was then terminated by washing the tissue three times with saline. The tissue was taken out of the instrument and the radioactivity of the exposed mucosa with the adhered bacteria was determined (13).

Statistical methods. All the experiments were done in duplicates. Results represent mean SD. An F test analysis of variance, followed by the $t$ test for multiple comparisons, were employed for the statistical analysis.

Scanning electron microscopy. After the assay for bacterial adherence, (with and without NIgF of human milk) the intestinal cells or intestinal mucosa were washed in saline, fixed with $2 \%$ glutaraldehyde for $1 \mathrm{~h}$, and washed with $0.1 \mathrm{M}$ sodium cacodylate buffer at $\mathrm{pH} 7.2$. They were then incubated with $1 \%$ osmium tetraoxide for $30 \mathrm{~min}$ and dried to a critical point. The tissue was fixed to planchets, coated with gold, and examined with a JSM-35c scanning electron microscope (Jeol, Japan).

\section{RESULTS}

The NIgF of human milk and colostrum, which were used throughout the study, were analyzed. The dry weight was similar $(22.4-22.6 \mathrm{mg} / \mathrm{ml})$, and their protein and sugar content are shown in Table 1.

Morphological observations with scanning electron microscopy clearly demonstrated that the bacteria examined adhered well to the microvillous surface of the small intestine, with reduction of the attachment by incubation with the $\mathrm{NIgF}$ of human milk. In Figure 1 the attachment of E. coli E1392 to the surface of the jejunum is demonstrated.

Adherence to intestinal cells. Quantitative determinations showed that the attachment of the bacteria examined was 13-17 bacteria per cell. Adherence was temperature (optimal $37^{\circ} \mathrm{C}$ ) and $\mathrm{pH}$ (optimal 6.2) dependent. Addition of NIgF of human milk or colostrum caused significant inhibition of the adherence of $E$. coli $\mathrm{E} 1392$ and $\mathrm{H} 10407$ (Fig. 2), bacteria which possessed CFA/I or CFA/II. The inhibitory effect of human milk and colostrum samples was similar, reducing the attachment of these bacteria to intestinal cells by approximately $50 \%$. On the other hand, no inhibition was noted on the attachment of $E$. coli 0128 , which possessed mannose-sensitive type I pili and not CFA (Fig. 2).

The influence of the amount of human milk added on the

Table 1. Analysis of NIgF of human milk and colostrum used in study*

\begin{tabular}{lcc}
\hline \multicolumn{1}{c}{ Determinant } & $\begin{array}{c}\text { Human } \\
\text { milk }\end{array}$ & $\begin{array}{c}\text { Human } \\
\text { colostrum }\end{array}$ \\
\hline Dry wt $(\mathrm{mg} / \mathrm{ml})$ & 22.4 & 22.6 \\
Protein content $(\mathrm{mg} / \mathrm{ml})$ & 1.1 & 2.1 \\
Sugar content $(\mathrm{mg} / \mathrm{ml})$ & 6.0 & 5.1 \\
\hline
\end{tabular}

* The dry weight was determined after lyophilization. The protein content was determined according to Lowry et al. (19) and the sugar content as described by Dubois et al. (20). 

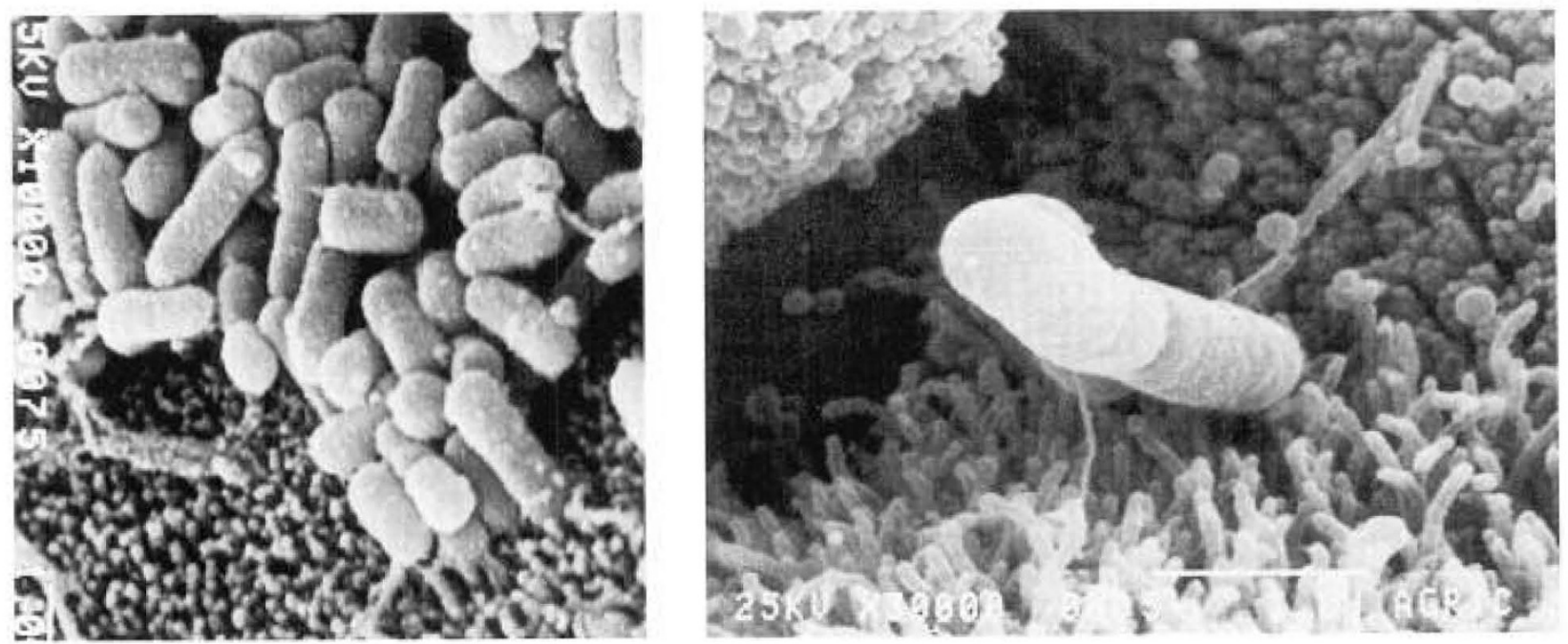

Fig. 1. Scanning electron micrographs of the adherence of $E$. coli E1392 to intact intestinal surface of guinea pig. $A$ (left), bacteria are seen on the epithelial surface of the small intestine $(\times 10,000)$. $B($ right $)$, higher magnification $(\times 30,000)$ showing bacteria attached to the brush border of an intestinal cell.

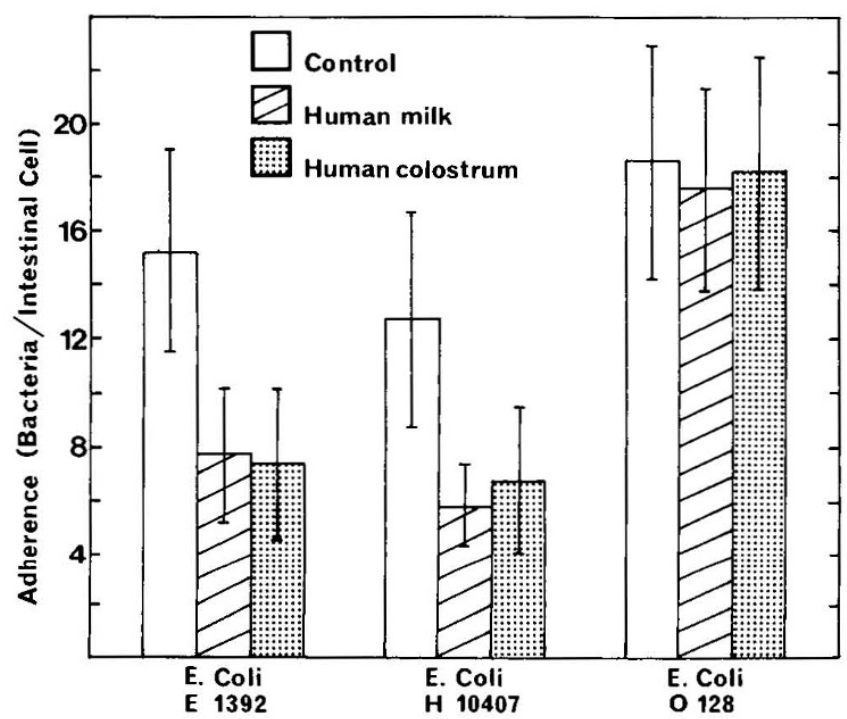

Fig. 2. The effect of NIgF of human milk and colostrum on the adherence of ETEC to guinea pig intestinal cells. Two hundred $\mu \mathrm{l}$ of human milk $(4.5 \mathrm{mg})$ or PBS (control) were preincubated with radiolabeled bacteria $\left(15 \mathrm{~min}, 37^{\circ} \mathrm{C}\right)$ and then the reaction was performed as described. Results represent mean $\pm \mathrm{SD}$ of eight determinations. $p$ values, calculated as compared to the control group, were significant for $E$. coli E $1392(p<0.001)$ and for E. coli $0128(p<0.01)$.

inhibitory effect was examined (Fig. 3). It was found that the inhibition increased as higher amounts were added, the maximal effect (59\% inhibition) has achieved at $300 \mu \mathrm{l}(6.7 \mathrm{mg})$ of NIgF of human milk. Higher amounts of NIgF of human milk did not increase the inhibition; moreover, it caused agglutination of the bacteria and therefore augmentated the number of the adhered bacteria.

In order to elucidate the mechanism of the inhibitory effects and find out the type of the involved compounds, several pretreatments of NIgF human milk samples were undertaken. Heating $\left(100^{\circ} \mathrm{C}, 10 \mathrm{~min}\right)$ and proteolytic digestion with trypsin (final concentration $2 \mathrm{mg} / \mathrm{ml}, 2 \mathrm{mg}$ enzyme $/ \mathrm{ml}$ of milk contained 22.4 $\mathrm{mg}$ of solids, of which proteins were $1.1 \mathrm{mg}, 60$-min incubation, and then boiling for $10 \mathrm{~min}$ to stop the enzymatic activity) did not abolish the inhibitory effect. In contrast, pretreatment of NIgF of human milk with sodium periodate (final concentration

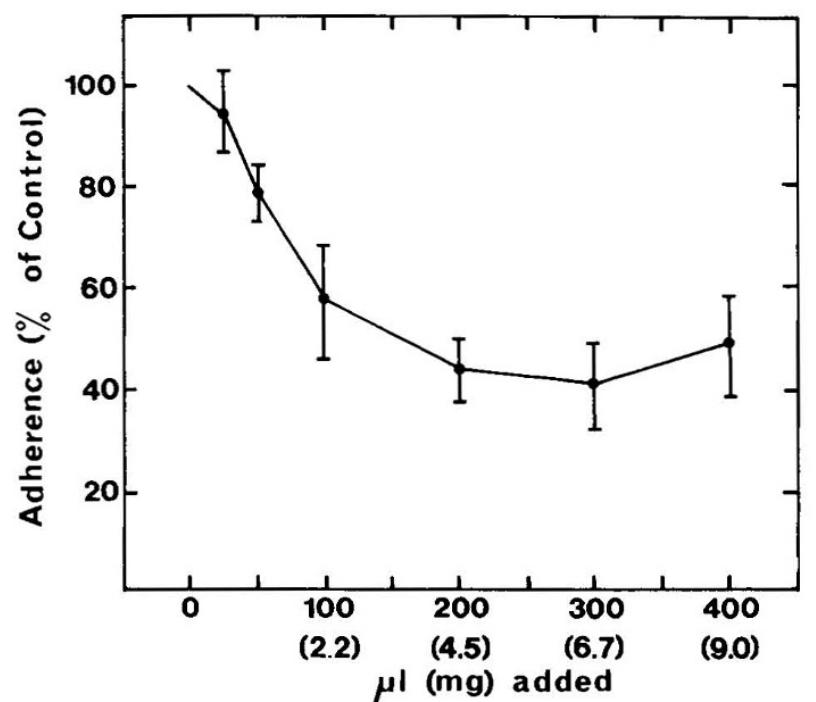

Fig. 3. The effect of the amount of NIgF of human milk added on the adherence of $E$. coli E1392 to guinea pig intestinal cells. Results represent mean $\pm \mathrm{SD}$ of five determinations. The dry weight of the sample was $22.4 \mathrm{mg} / \mathrm{ml}$.

$10 \mathrm{mM}, 60 \mathrm{~min}$ ) which oxidizes carbohydrate molecules containing vicinal hydroxyl groups, completely abolished the inhibitory effect on bacterial adherence (Table 2).

Adherence to intact intestinal surfaces. These experiments were performed in order to correlate the adherence to a suspension of intestinal cells in vitro with the binding to an intact intestinal surface. The adherence is morphologically shown in Figure 1. Quantitative determinations showed that $(13.2-20.8) \times 10^{5}$ bacteria adhered to each area of the exposed jejunal mucosa (Table 3). NIgF of human milk and colostrum caused 38 to $43 \%$ inhibition of the adherence of ETEC E1392 and H10407, but did not inhibit the adherence of $E$. coli 0128 (Table 3 ) as found in the previous experiments in vitro.

\section{DISCUSSION}

The main finding of this study is the significant inhibitory effect of NIgF of human milk on the adherence of ETEC to the small intestine. The inhibition was limited to bacteria whose 
Table 2. Effect of pretreatments of NIgF of human milk on its inhibition of bacterial adherence*

\begin{tabular}{llc}
\hline \multicolumn{1}{c}{ Pretreatment } & $\begin{array}{c}\text { Concentration } \\
\text { and duration }\end{array}$ & $\begin{array}{c}\text { Inhibition of } \\
\text { adherence } \\
(\%)\end{array}$ \\
\hline No pretreatment (control) & & $56 \pm 6$ \\
Heating & $100^{\circ} \mathrm{C}, 10 \mathrm{~min}$ & $50 \pm 10$ \\
Trypsin & $2 \mathrm{mg} / \mathrm{ml}, 60 \mathrm{~min}$ & $54 \pm 10$ \\
Periodate $\dagger$ & $10 \mathrm{mM}, 60 \mathrm{~min}$ & $1 \pm 1$ \\
\hline
\end{tabular}

${ }^{*}$ In these experiments the effect of $300 \mu \mathrm{l}(6.7 \mathrm{mg})$ of NIgF of human milk with and without pretreatments on the adherence of $E$. coli $\mathrm{E} 1392$ to guinea pig intestinal cells was determined as described in the text. Results represent mean \pm SD of three determinations.

$\dagger$ The effect of periodate treatment was highly significant $(p<0.001)$.

Table 3. Effect of nonimmunoglobulin fraction of human milk and colostrum on the adherence of ETEC strains to intact intestinal surfaces

\begin{tabular}{llcc}
\hline Bacteria & $\begin{array}{l}\text { Compound added } \\
(200 \mu 1,4.5 \mathrm{mg})\end{array}$ & $\begin{array}{c}\text { Adherence* } \\
\left.\text { (bacteria } \times 10^{5}\right)\end{array}$ & $\begin{array}{c}\text { Significance } \dagger \\
(p)\end{array}$ \\
\hline E. coli $\mathrm{E} 1392$ & PBS (control) & $16.1 \pm 4.2$ & \\
& Human milk & $9.3 \pm 2.2$ & $<0.02$ \\
& Human colostrum & $9.5 \pm 2.0$ & $<0.02$ \\
E. coli $\mathrm{H} 10407$ & PBS (control) & $13.2 \pm 4.4$ & \\
& Human milk & $7.8 \pm 2.0$ & $<0.05$ \\
& Human colostrum & $8.1 \pm 2.7$ & $\mathrm{NS}$ \\
E. coli 0128 & PBS (control) & $20.8 \pm 4.0$ & \\
& Human milk & $21.2 \pm 4.2$ & $\mathrm{NS}$ \\
& Human colostrum & $21.0 \pm 5.4$ & $\mathrm{NS}$ \\
\hline
\end{tabular}

* Results presented as the number of bacteria adhered to $0.38 \mathrm{~cm}^{2}$ area of exposed intestinal mucosa. They represent mean \pm SD of five determinations. The detailed experimental conditions are described under in "Materials and Methods".

$\dagger p$ values calculated as compared to the control (PBS) group.

adherence was mediated by CFA/I and CFA/II. These antigens were isolated from human strains of $E$. coli and recently characterized as immunologically and morphologically distinct proteins (11). No inhibition was found on the adherence of ETEC strains which possessed mannose-sensitive type I pili, such as $E$. coli 0128 .

Holmgren et al. (6) have shown that human milk inhibits the hemagglutination caused by $E$. coli and $V$. cholerae, which depends on bacterial attachment to erythrocytes. Fractionation of the milk indicated that its glycoprotein and oligosaccharide components were responsible for the inhibition of $V$. choleraeinduced hemagglutination (21). It was also demonstrated that human milk protected against enterotoxin-induced diarrhea in rabbits (22). Herein the issue was further explored and the effect of human milk on the actual adherence of the bacteria to the intestine was directly and quantitatively determined.

The nonimmunoglobulin-dependent inhibition of bacterial adherence is probably caused by receptor-like glycocompounds in human milk that are structural analogues of the intestinal receptors for bacterial surface proteins. The inhibitory activity resisted boiling and proteolytic digestion with trypsin, but was abolished by periodate treatment, indicating that sugar residues are probably the responsible moiety. This fits with many previous studies which documented inhibition of bacterial adherence by carbohydrate residues $(9,13,23)$. In the future detailed structural determination of the component(s) in human milk which inhibits adherence will be required. In addition, examination of the protective effect of human milk obtained from women of different socioeconomic and ethnical groups should be undertaken.

Caution is needed in any extrapolation of results obtained in animals to humans. Similar experiments in man have obvious limitations. Deneke et al. (24) have recently described a method of obtaining human intestinal cells from long-standing ileostomies (24). Using this approach, similar determinations with human cells can be undertaken.

Although considerable work is still needed and studies are in progress, it seems that a new mechanism by which human milk protects against intestinal infection may exist, as previously suggested by in vitro hemagglutination inhibition (6). This protection of human milk is well documented (2-4) and was traditionally attributed to its Ig content. However, Ig may be destroyed by intestinal digestive enzymes and their titer against intestinal pathogens is reduced in developed countries (6). It was, for example, shown that immunoglobulins play only a minor role in the inhibitory activity of human milk obtained from Swedish mothers against $E$. coli $(6)$ and $V$. cholerae (21) adhesion to erythrocytes.

We have recently shown that bacterial adherence to the intestinal tract depends on the postnatal age and it may play a role in the development of the normal bacterial flora and the appearance of intestinal infections $(14,25)$. Infections with ETEC are important in infancy and depend on the adherence of the bacteria to the gut (18). Since our results show that human milk can inhibit the adherence of certain ETEC strains to the gut, it is suggested that this mechanism may play a role in protecting infants against intestinal infections.

\section{REFERENCES}

1. Larsen SA, Homer DR 1978 Relation of breast versus bottle feeding to hospitalization for gastroenteritis in a middle class U.S. population. J Pediatr 92:417-418

2. Cunningham SS 1979 Morbidity in breast-fed and artificially fed infants. II. J Pediatr 96:685-689

3. Myers MG, Fomon SJ, Koontz FP, McGuinness GA, Lachenbruch PA, Hollingshead R 1984 Respiratory and gastrointestinal illness in breast-fed and formula-fed infants. Am J Dis Child 138:629-632

4. Kovar MG, Serdula MK, Marks JS, Fraser DW 1984 Review of the epidemiologic evidence for an association between infant feeding and infant health. Pediatrics 74 (suppl):619-628

5. Hanson LA, Ahlstedt S, Andersson B, Carlsson B, Fallstrom SP, Mellander L, Porras O, Soderstrom T, Svanborg Eden C 1985 Protective factors in milk and the development of the immune system. Pediatrics 75(suppl):172-176

6. Holmgren J, Svennerholm AM, Ahren C 1981 Nonimmunoglobulin fraction of human milk inhibits bacterial adhesion (hemagglutination) and enterotoxin binding of Escherichia coli and Vibrio cholerae. Infect Immun 33:136141

7. Stephens S, Dolby JM, Montreuil J, Spik G 1980 Differences in inhibition of the growth of commensal and enteropathogenic strains of Escherichia coli by lactotransferrin and secretory immunoglobulin $\mathrm{A}$ isolated from human milk. Immunology 41:597-603

8. Ofek I, Beachey EH 1980 Bacterial adherence. Adv Intern Med 25:503-532

9. Editorial 1981 Microbial adhesion, colonization and virulence. Lancet 2:508510

10. Boedeker EC 1982 Enterocyte adherence of Escherichia coli: its relation to diarrheal disease. Gastroenterology 83:489-492

11. Gaastra W, deGraaf FK 1982 Host-specific fimbrial adhesions of noninvasive enterotoxigenic Escherichia coli strains. Microbiol Rev 46:129-161

12. Mirelman D, Altmann G, Eshdat Y 1980 Screening of bacterial isolates for mannose-specific lectin activity by agglutination of yeasts. J Clin Microbiol 11:328-331

13. Izhar M, Nuchamowitz Y, Mirelman D 1982 Adherence of Shigella flexneri to guinea pig intestinal cells is mediated by a mucosal adhesion. Infect Immun 35:1110-1118

14. Ashkenazi S, Mirelman D 1984 The effect of postnatal age on the adherence of Shigella flexneri, Escherichia coli 0124 and E. coli 0128 to guinea pig intestinal cells. Pediatr Res 18:1366-1371

15. Kobata A 1977 Milk glycoprotein and oligosaccharides. In: Horowitz MM, Pigman W (eds) The Glycoconjugates. Academic Press, New York, pp 423440

16. Ashkenazi S 1986 Adherence of nonfimbriate enteroinvasive Escherichia coli 0124 to guinea pig intestinal tract. In vitro and in vivo. J Med Microbiol 21:117-123

17. Miron T, Wilchek M 1987 Immobilization of proteins and ligands using chlorocarbonates. Methods Enzymol (in press)

18. Weir DM (ed) 1978 Handbook of Experimental Immunology. Blackwell Scientific Publications, Boston, MA, pp 15.18-19.17

19. Lowry OH, Rosebrough NJ, Farr AL, Randall RJ 1951 Protein measurements with the Folin phenol reagent. J Biol Chem 193:265-275

20. Dubois M, Gilles KA, Hamilton JD, Rebers PA, Smith F 1956 Colorimetric method for the determination of sugars and related substances. Anal Chem 28:350-356 
21. Holmgren J, Svennerholm AM, Lindband M 1983 Receptor-like glycocompounds in human milk that inhibit classical and El Tor Vibrio cholerae cell adherence (hemagglutination). Infect Immun 39:147-154

22. Otnaess AB, Svennerholm AM 1982 Non-immunoglobulin fraction of human milk protects rabbits against enterotoxin-induced intestinal fluid secretion. Infect Immun 35:738-740

23. Ofek I, Mirelman D, Sharon N 1977 Adherence of $E$. coli to human mucosal cells is mediated by mannose receptors. Nature 265:623-625
24. Deneke CF, McGowan K, Thorne GM, Gorbach SC 1983. Attachment of enterotoxigenic Escherichia coli to human intenstinal cells. Infect Immun 39:1102-1106

25. Ashkenazi S, Dinari G, Mirelman D 1986 The ontogeny of bacterial adherence to the gut. Animal studies and their relation to human intestinal disease. In: Branski D, Dinari G, Rozen P, Walker-Smith JA (eds) Pediatric Gastroenterology, Aspects of Immunology and Infections. Karger, Basel, pp 284-292

\section{Announcement}

The ASSOCIATION OF MEDICAL SCHOOL PEDIATRIC DEPARTMENT CHAIRMEN, INC. proudly announces the Pediatric Scientist Training Program 1987 Fellows

Name

Kendall Brown, M.D.

George T. Capone, M.D.

Darryl C. Longee, M.D.

Karen McAlmon, M.D.

Lasurie C. Miller, M.D.

Sharon A. Nachman, M.D.

Michael R. Narkewicz, M.D.

Scott A. Rivkees, M.D.
Sponsoring Department and Chairman University of Texas, Dallas Joseph B. Warshaw, M.D. Children's Hospital Medical Center, Cincinnati

William K. Schubert, M.D. Duke University Samuel L. Katz, M.D.

Boston Children's Hospital David G. Nathan, M.D.

Tufts University

Jane G. Schaller, M.D.

New York Medical College Edward Wasserman, M.D.

University of Colorado

Frederick C. Battaglia, M.D.

Harvard Medical School Donald M. Medearis, Jr., M.D.

and gratefully acknowledges the support and sponsorship of National Institute of Child Health and Human Development

March of Dimes Birth Defectgs Foundation

Cystic Fibrosis Foundation

St. Jude Children's Research Hospital 